\author{
Alicja Matgorzata Graczyk*
}

\title{
IMPLEMENTATION OF SUSTAINABLE DEVELOPMENT IN THE CITY OF HEIDELBERG ${ }^{1}$
}

\begin{abstract}
The city of Heidelberg has won twice the price of European Sustainable City Award. The paper presents the latest author's investigation (July 2014) about the sustainable development in the Heidelberg. The goal of the article is the analysis and the assessment of tasks connected with implementation of sustainable development in the city of Heidelberg. In the first part an analysis of the execution of pro-environment actions will be carried out. The second part of the analysis will be related to economic activities, and the third part - to social activities. The mode of integration of the executed actions and of the instruments used shall be presented in the summary. The introduction shall present the genesis of sustainable growth in Heidelberg, as well as examples of actions used in European green cities. The research objective is justified by the necessity of promoting positive models of city management according to the idea of sustainable development. Thus the final part puts forth recommendations for Polish cities.
\end{abstract}

Keywords: sustainable development, city, implementation, climate protection.

\section{INTRODUCTION}

Sustainable development is understood as "development that meets the needs of the present without compromising the ability of future generations to meet their own needs" (Our Common Future: 43). The essence of sustainable development is the integration of politics, economy and social actions with basic environmental actions (Bukowski 2005: 118). Public authorities were burdened with this obligation as they lead political actions, set and shape the rules of economic and social activity and control the activity.

Sustainability is often interpreted as a goal to reach in political categories or a goal related to strategic actions (sustainable development strategies of cities or communes). It may also be seen this way when interpreting the actions of the Heidelberg city authorities. The challenge of sustainable development policy in the city concentrates on climate protection, passive building construction, ecological

* Wroclaw University of Economics, Faculty of Engineering and Economics, Chair of Economics and Research on Development.

${ }^{1}$ The project was financed by the National Science Centre, decision number: DEC-2012/07/D/ HS4/00733. 
manufacturing as well as low energy consumption, ecological transport and cooperation with citizens. The Heidelberg authorities takes responsibility for social co-existence and preservation of an environment with a high quality of living in an economically successful community.

The goal of the article is the analysis and the assessment of tasks connected with implementation of sustainable development in the city of Heidelberg. In the first part an analysis of the execution of pro-environment actions will be carried out. The second part of the analysis will be related to economic activities, and the third part - to social activities. The mode of integration of the executed actions and of the instruments used shall be presented in the summary. The introduction shall present the genesis of sustainable growth in Heidelberg, as well as examples of actions used in European green cities. The research objective is justified by the necessity of promoting positive models of city management according to the idea of sustainable development. Thus the final part puts forth recommendations for Polish cities.

\section{THE SUSTAINABLE CITY DEVELOPMENT IN THE EU}

In 24-27 May 1994, 80 local authorities gathered in Aalborg (Denmark) for a ground breaking conference on local sustainability. The conference can be considered as the European equivalent of the Earth Summit's Agenda 21. The goal of the meeting was to spreading the local sustainable development message across Europe in the period following the Rio Earth Summit. A special political document by which cities and towns committed to the promotion of urban sustainability in their localities were signed and called as the Charter of European Cities \& Towns Towards Sustainability (Aalborg Charter). 80 European municipalities signed the Aalborg Charter (over 3,000 signatories) (First European Conference 1994).

The Second European Conference on Sustainable Cities \& Towns, held in Lisbon, Portugal in October 1996. During the conference the principles of the Aalborg Charter were introduced into more practical measures and resulted in the adoption of the Lisbon Action Plan. The both documents provide a basic framework to support local and regional authorities striving for sustainable development. Action Plan shows that support from the municipal leader as well as training of elected representatives and officers on sustainability concepts are essential. Moreover local sustainability is made up of social, economic and environmental sustainability so that a cross-sector approach is indispensable (The Lisboa Action Plan).

There are several cities that conduct sustainable development policy. One of them is Hamburg and Bristol. Hamburg, the European Green Capital of 2011, has set ambitious climate protection goals such as reducing its $\mathrm{CO}_{2}$ emissions by $40 \%$ by 2020 and by $80 \%$ by the year 2050 . Worth to mention is that all citizens 
have access to optimal public transport within 300 meters of their given location. Hamburg increases its green areas, has introduced environmental zones, has built a new network of cycle paths, city railway $(40 \mathrm{~km})$. Hamburg has become a leader in a new construction standards, reducing energy consumption of existing buildings. The city also increases wind energy production (Maaß 2014). A number of heating plants have been converted into cogeneration plants. Hamburg offers subsidies for building owners who make available their roof surfaces for photo-voltaic plants. This programme also considered subsidises bio-energy plants, such as pellet heating plants or cogeneration plants. Concerning energy efficiency, the following steps were undertaken: the "Wohnungsbaukreditanstalt" (Residential Development Loan Corporation) owned by Hamburg funds the modernisation of 4,000 residential units with annually 10,000,000 euros, "Lamp exchange 2:1 for the climate", "fifty/fifty", boiler and refrigerator replacement, GreenLight Programme (Hamburg had replaced over 200,000 conventional lamps in more than 400 public buildings with energy-saving lights). "Hamburg learns sustainability" is an initiative for the educational work created for enterprises, municipal authorities, education institutions, citizens and experts from all sectors. They published an action plan, which encompasses 110 education measures, amongst them numerous related to climate protection.

Bristol, the UK's greenest city, has consistently reduced carbon emissions since 2005 . The city has set ambitious targets to reduce $\mathrm{CO}_{2}$ emissions by $40 \%$ by 2020 and $80 \%$ by 2050 (from 2005 baseline) and energy use by 30\%. 76\% of people in Bristol are within $300 \mathrm{~m}$ of an hourly (or more frequent) public transport service. The city has successfully reduced commuting by private car by f.e. improving public transport and cycling. Key actions included such instruments as: a dedicated "road show" - cycling festivals, loan bikes for people, training for citizens. The results show $80 \%$ increase in cycling since 2004 . Bristol is reducing city centre parking by park and ride system letting travellers park a car and travel by public transport or bicycle to the city center. Another useful solution is city parking control which discourage commuting by car (Public Realm ..., UK Department 2012). 88\% of Bristol residents live within $300 \mathrm{~m}$ of a green space, including $87 \%$ of the inner-city population (Core Strategy 2014). Since 2008 the city has been developing community engagement by Neighbourhood Partnerships Network of over 25 local residents planning groups. Environmental Technology Innovation Network transfer the knowledge and ensure innovation partnership between Bristol City Council, business, scientists from universities, organisations supporting sustainable development solutions f.e. the Centre for Sustainable Energy on domestic energy efficiency. Social innovation is practised by engaging stakeholders and the local community in sustainable actions. For instance Bristol Green Doors enable green citizens to open their homes to visitors to demonstrate energy saving and renewable energy savings measures. The result was that $70 \%$ of visitors were "more likely to install relat- 
ed solutions" after this visit. Bristol City area has over around 700 hybrid and electric vehicles (2011) and this has increased by 374\% in for years 2007-2011 (Bristol. Smart City 2011).

\section{THE ROOTS OF SUSTAINABLE DEVELOPMENT IN THE HEIDELBERG}

At the early stage Heidelberg committed itself to goals which were latter laid down in Agenda 21 by the Conference on Environment and Development in Rio de Janeiro. The previous development plan of the city dating from 1974 was committed to the aspects of the quality of life, cityscape and landscape, traffic burden, job structure (Heidelberg City Development Plan 1984: 3). The presented objectives were future-orientated and outlined the unique character of the city based on nature preservation and quality of life improvement of its citizens. What is unique of city are its green surroundings - mixture of urban and rural uses, smallness, unobtrusiveness and cosiness, student atmosphere. University and other education and research institutions, open-mindedness and tolerance towards strangers are additional advantages of Heidelberg. Due to high number of students the Heidelberg University has an important impact on the economic development, the volume of housing demand. It also gives the impulses for developing the "information society". Consequently Heidelberg supports cooperation between the science and business sector. The city has over 150,000 residents, 21,000 out of this is foreigners and 30,000 students. The total area is $108.8 \mathrm{~km}^{2}$, where $29 \%$ is build area, $41 \%$ forests and $27 \%$ agriculture (The inteview with dr Raino Winkler 2014).

In the 1992 Heidelberg $\mathrm{CO}_{2}$ reduction concept was introduced (Institut für Energie 2014). This strategy was developed in order to reduce greenhouse gases for the first time in all sectors of a city. In the 1997 took place the Round Table Energy funding of the regional energy advice agency and one year later Round Table „Sustainable Management” and Round Table Nature Preservation. In the $21^{\text {th }}$ century the city has become a symbol of urban quality of life. Compared to the 1974 the number of jobs increased by 20,000 and the number of dwellings by 16,000 although the number of inhabitants has only slightly risen. The transformation of family and household structures, diverse lifestyles, multicultural inhabitant structure are the characteristic of major changes. Many European cities meanwhile strive to launch a sustainability campaign for this purpose, Heidelberg joined this campaign by signing the Aalborg Charter.

The city of Heidelberg has won twice the price of European Sustainable City Award. The Sustainable city award can be won within the Campaign for Sustainable Cities. Local and regional authorities from the European Union, Candidate countries or even European Economic Area can apply the program. A special 
framework programme is organised in different strands (sub-programmes) (European Sustainable City Award). The main areas concerned are city planning, local development, environment.

Heidelberg goals are to achieve a socially responsible, environmental friendly and economically successful future city and retain its unique character. The main local priorities for sustainable development are: citizens cooperation in decision making process, climate and environment protection, rising energy efficiency by using renewable energy sources, local heat district, ecological transport and building in passive standard.

\section{CITY ENVIRONMENTAL MANAGEMENT}

Ecological aspects take centre stage in Heidelberg. First of all the local authorities educate the next generation. A special program called The Education for Sustainable Development were designed to teach children from an early age how their behaviour affects the environment. Moreover, popular series of events titled "Heidelberg... naturally" teaches parents and children the importance of nature and environment protection (The City of Heidelberg 2014). Secondly, the city cares for reliable garbage disposal by providing a special hotline to answer any questions of residents and city cleaning service with comparatively low charges. In addition the residents demonstrate their commitment in community action events such as the spring clean and by carefully separating their garbage. This in turn contributes to sustainable recycling because Heidelberg's organic waste is turned into high-quality compost (Bahnstadt 2014).

$\mathrm{CO}_{2}$ emissions of the Federal Republic of Germany are expected to fall in 2020 to $40 \%$ in comparison to the level of 1990. Local Climate Protection is one of the key issues of environment protection and essential element of sustainable development of the city. A core element for the concept development has been the extensive involvement of key stakeholders in the city. After implementing the Heidelberg $\mathrm{CO}_{2}$ reduction concept in 1992, concerning reduction of greenhouse gases in all sectors of a city, Heidelberg continued climate protection on rising energy efficiency and the using of renewable energies (Institut für Energie). Existing concept have been continuously improved and adapted for municipal use (e.g. the grid for climate protection measures). The city committed itself to reducing the carbon dioxide emissions by at least $20 \%$ by the year 2005 (with respect to the 1987 values). One of the crucial activity is $\mathrm{CO}_{2}$ accounting, climate protection benchmark and in the development of support programs for the implementation of mitigation measures. Target groups include consumers and suppliers as well as municipalities, states and the federal government. The measures introduced so far are: slowing down the traffic, technical consulting when spare energy sources, 
promotion of public transport, use of renewable energy sources. According to the Clean Air Plan for Mannheim/Heidelberg area number of environmental objectives were adopted for reducing air pollution (nitrogen dioxide, benzene, diesel soot, ozone).

The city council also implemented the Master Plan " $100 \%$ Climate Change Mitigation in Heidelberg" in July 2014 (Konzept für den Masterplan). The Federal Ministry for the Environment, Nature Conservation and Nuclear Safety is currently funding 19 German municipalities within the scope of "The Climate Initiative". This is a national scheme to support climate change mitigation measures. The participating municipalities have accepted the goal to reduce their levels of greenhouse gas emissions by a minimum of $95 \%$ by the year 2050 . Heidelberg commissioned the IFEU (Institut für Energie- und Umweltforschung Heidelberg $\mathrm{GmbH}$ ) to develop the conceptual framework for Phase 1 requires city to develop a plan outlining concepts on how to achieve the highly ambitious aims of the initiative, as well as identifying the practical measures entailed. It means the calculation of a current carbon footprint of the city as well as the computation of predictive models that illustrate potential scenarios for the time span between now and 2050. The framework includes the traffic sector, the energy sector including the integration of renewable energy sources, and the involvement of local consumers in households and public buildings as well as resident commerce, tourism industry, the university and the historic centre of Heidelberg.

\section{SUSTAINABLE ECONOMIC DEVELOPMENT}

Implementation of sustainable economic development in the city is mainly carried out in the following areas: energy-efficient buildings, development of sustainable energy sources, environment-friendly transport and promotion of the development of small and medium enterprises with a profile that is compatible with sustainable development.

In Germany about 28 million homes were built before 1978. Their mean annual demand for heat is about $159 \mathrm{kWh} / \mathrm{m}^{2}$. In Heidelberg, near the Neckar river, there are about 315,000 buildings that were built before 1978, 14,930 are residential buildings (Stadtentwicklung in Heidelberg 2010: 14). Standard of existing buildings is below the required (Energy Saving Ordinance 2009). In the energy plan conception in 2010, the city of Heidelberg meet for their own buildings the energy standards adopted by the city council (see fig. 1). The energy standard for new buildings was set at the maximum level of $66 \mathrm{kWh} / \mathrm{m}^{2}$ per year. According to the city the energy consumption of urban property has been reduced in recent years by about $50 \%$. 
Heidelberg is now famous for its new ecological district. Bahnstadt is a special model of sustainable urban construction. It is the biggest passive building concentration in the word. It is not only environmentally friendly but also highly cost effective project. Nowadays, companies are looking for city-centre locations where their employees can both work and relax. Bahnstadt is one of Germany's biggest urban development projects. It is located just a few minutes' walk from Heidelberg Central Station. It covers 116 hectares, an area bigger than Heidelberg's Altstadt (Old City). According to estimates, around 2 billion euros will be invested in the new district. The project is partnered by Entwicklungsgesellschaft Heidelberg (EGH), which is responsible for developing and marketing much of the site (The City of Heidelberg 2014).

All of the buildings in the district will comply with rigorous passive-house building standards. It is estimated that 12,000 people will live and work there. The Bahnstadt centrepiece will be SkyLabs - a building housing $19,000 \mathrm{~m}^{2}$ of office and laboratory space for scientific and high-tech companies. Planned apartment buildings will accommodate 5,000 residents. In addition shops, two state-run nurseries, an elementary school, play areas, green spaces, a cinema are planned to be built (Bahnstadt).

One of the main trends of sustainable development implementation is expansion of the "Heidelberg standards" to passive house standard. Heidelberg adopted the Passive House Standard which is specified for all new buildings. The city subsidises the citizens building passive houses with $50 €$ per $1 \mathrm{~m}^{2}$ and $5,000 €$ per family, but no more than $12,500 €$ per house (The inteview with $d r$ Raino Winkler 2014).

City development in Heidelberg from an environmental perspective involves the installation of a modern heating system, using solar collectors or photovoltaic systems. It is recognised that $85 \%$ of public buildings in the city are heated by the district heat. No more than $2 \%$ of citizens uses the electric power for heating. Natural gas is still popular source of power. The renewable energy sources are highly recommended to be used by citizens. By now, Heidelberg uses: wind power turbines, photovoltaics, hydropower (40 MW of installed capacity), solar thermal and biomass (c.a. $50 \mathrm{MW}$ biomass $-40 \%$ of district heating comes from biomass). The city funding for citizens the renovating/buying new thermal or solar thermal installations, building passive houses has spent c.a. $1,300,000 €$ per year.

Recommendations of the Heidelberg City Council in the area of energy efficiency in buildings include: identification and assessment of the alignment of existing buildings in relation to crucial directions, especially the examination of the angle of the roof, investigation into the opportunities of installing sustainable energy sources. City authorities also plan to introduce environmental rent after the example of Berlin, Bochum, Darmstadt, Erlangen, Hamburg, Magdeburg and Münster. 
In the period from 1993 to 2009 , the city has supported a total of 2,600 projects with their own program for rational energy use, which are annually about 150 measures. The city subsidies for energy were total of 5,500,000€.

Road traffic as a source of pollution accounts for approximately $65 \%$ of air polluting emissions. Therefore the city promotes environment-friendly transport. Electric trams and electric railways run through the city, and the citizens are able to use bicycle transport. The city introduced so far: slowing down the traffic, promotion of public transport and donation for electric and $\mathrm{CNG}$ vehicles. If the resident buys an electric car is donated 1000 euro. By now there is over 200 electric and hybrid cars in the city. The city implemented Noise mitigation plan according to traffic noise. It includes the following points (The inteview with dr Raino Winkler 2014):

- limiting the movement of vehicles to 16,400 vehicles per 24 hours,

- limiting the speed to $30 \mathrm{~km} / \mathrm{h}$ between $10 \mathrm{PM}$ and $6 \mathrm{AM}$,

- underpinning the roads with damping materials,

- supporting bicycle transport through construction investments,

- stationary speed control through radars,

- building a tunnel by the Neckar shore.

The city generates over 110,000 places of employment, over $83 \%$ people work in the service sector (The inteview with $d r$ Raino Winkler 2014). New companies are promoted if they are compatible with the main objectives of urban development. Innovative enterprises especially in the field of environment research and technology are very welcomed in the city. Furthermore, the city promotes novel projects for an active, sustainable employment policy as well as projects for economic self-help. In addition Heidelberg supports close cooperation between the science and industry sectors, meeting the criteria of sustainable economy, for instance close cooperation with the Heidelberg university and existing research institutions. The city is also the moderator of cooperation between science and industry helping to transfer university knowledge to industry and contribute to innovative development (f.e. Technology Park). Social and ecological aspects of conducting business are taken into account, especially those which strengthen local craft shops. It concerns especially medium-sized enterprises and manual trade. City also promotes strengthening the women position on labour market to ensure the independence and labour protection. Reducing the use of land in the industry is one of sustainable development goals of the Heidelberg. Additional land for industrial use will be provided only if a higher utilisation rate is not sufficient to achieve the economic objectives. Land must be used more economically in view of general scarcity of resources and its requirements. Economic development should be compatible with social interests, natural environment and landscape requirements. 


\section{SUSTAINABLE SOCIAL DEVELOPMENT}

The objective of a sustainable development cannot be achieved without the support of citizens. Heidelberg now tries to meet the challenge of demographic change. It tries to be family-friendly, creative, open-minded and tolerant city for all generations. The framework conditions for these goals are friendly housing, employment, childcare and better education.

Cleanness and care for environment is the result of the local authorities and citizens cooperation. The city supports citizen commitment for sustainable development at the local level. The City Development Plan (Heidelberg City Development Plan 2015 (2007): 4) has been prepared in cooperation with citizens. Consultations, public involvement via internet and local paper, discussions with League of Voluntary Welfare Work and Foreigners Council helped to prepare and introduce many interesting ideas.

It is intended to put the local Agenda 21 process on a broad societal basis. In order to promote the social actors participation it is planned to create the special operational structure. It will help to develop autonomous activities and give people the possibility to influence political decisions. Each planning should be ecologically and socially justifiable. Any form of community participation requires a considerable amount of time for communication, cooperation and conflict. Access for woman is very important to mobilise the groups which have hitherto stayed out of politics. City supports gender equality, variety of lifestyle choices.

One of the objectives of urban planning is to ensure sustainable social development by enable all persons to reach the entire range of living opportunities in the Heidelberg without any obstacles and use them without assistance. Promoting independent lifestyle, interaction among citizens of diverse races, religion, ages, mutual cooperation, activity in political city matters, solidarity, own initiatives, shapes the picture of city of social balance preventing marginalisation.

\section{INTEGRATION OF PRO-SUSTAINABLE-DEVELOPMENT ACTIONS}

Implementation of sustainable development in cities, meaning the integration of actions related to the economy, environment and society, consists of achieving environmentalist goals, e.g. climate protection while simultaneously considering their social and economic outcomes. We should note that environment-friendly cities, applying solutions pertaining to climate protection, enable their citizens to raise the standard and quality of their lives. Policies of environment-friendly transport not only fosters a cleaner environment, but also 
the healthy condition of citizens. A similar relation may be seen between using sustainable energy sources in a city and a cleaner environment. The sources allow the atmospheric emissions of carbon dioxide, as well as sulfur and nitrogen compounds, to be limited, which would otherwise be released when burning fossil fuels. Environment-friendly architecture increases the energy efficiency of buildings, which results in the lower costs of exploitation for inhabitants, and in a cleaner environment thanks to substituting fossil fuels with renewable sources. Lower exploitation fees let monetary assets be spent for other purposes. Climate protection activities cause positive social results (external benefits appear). The propagation and implementation of innovative solutions in the sphere of environmental protection encourages investments and the creation of new jobs (economic area).

It is important that the instruments used for sustainable development be applied at the right stage. The policy and economic instruments implemented at the local level at the very early stage help the city to build ecological education and shape ecological style of life.

\section{RECOMMENDATIONS FOR POLISH CITIES}

We may observe the beginnings of sustainable development actions in Polish cities. Since 2013 the "ECO-Miasto" competition is organized, initiated by the French embassy in Poland. Its goal is to promote the best practices related to the implementation of projects of sustainable development. In 201420 local government institutions took part. The winners were Zamość, Warszawa, Płońsk, Kościerzyna, and Ełk. The implemented projects pertained to energy-efficiency, low-emissions, environment-friendly architecture, and sustainable mobility policies. The capital won as the city of over 100,000 citizens in the categories of sustainable mobility and architecture. Polish cities were awarded for using the following solutions: energy-efficient trams, LPG-powered city busses, city systems of bicycle lease, limiting car traffic in the centre, promoting energy-efficient architecture.

Table 1 presents a list of the main legal and political instruments, which were instituted in environment-friendly cities, such as Heidelberg, Hamburg, or Bristol, and which contributed to the sustainable development in the regions. Introduction of similar instruments in Polish cities would surely increase the citizens' quality of life. The cities make integrated efforts by creating support programs for: the development of renewable energy, sustainable transportation, city heating network, energy-efficient architecture. They created associations, consortia and networks of cooperation between science, business, public institutions and citizens. 
Instruments for sustainable development implementation in the EU

\begin{tabular}{|c|c|c|}
\hline Heidelberg & Hamburg & Bristol \\
\hline $\begin{array}{l}\text { Subsidies electric and CNG } \\
\text { vehicles and passive housing. }\end{array}$ & $\begin{array}{l}\text { Subsidises bio-energy plants, } \\
\text { such as pellet heating plants or } \\
\text { cogeneration plants, subsidises } \\
\text { solarthermal plants. }\end{array}$ & $\begin{array}{l}\text { Cycle lanes, cycle } \\
\text { refurbishment schemes, } \\
\text { tax-free incentive for bicycle } \\
\text { purchase. }\end{array}$ \\
\hline $\begin{array}{l}\text { Limiting the speed to } 30 \mathrm{~km} / \mathrm{h} \\
\text { between } 10 \mathrm{PM} \text { and } 6 \mathrm{AM} \text {. } \\
\text { Reducing automobile traffic, } \\
\text { limiting the movement of } \\
\text { vehicles to } 16,400 \text { vehicles } \\
\text { per } 24 \text { hours. }\end{array}$ & $\begin{array}{l}\text { Energy efficiency: leader in } \\
\text { new construction standards; } \\
\text { reducing consumption of } \\
\text { existing old buildings. }\end{array}$ & $\begin{array}{l}\text { Park and ride system, } \\
\text { City Parking Control. }\end{array}$ \\
\hline $\begin{array}{l}\text { Programmes for investing in } \\
\text { renewable energy sources } \\
\text { (e.g. subsidies PV, solars). }\end{array}$ & $\begin{array}{l}\text { New city railway network } \\
(40 \mathrm{~km}) \text {, New suburban and } \\
\text { underground train lines to } \\
\text { HafenCity and airport. }\end{array}$ & $\begin{array}{l}20 \mathrm{~m} / \mathrm{h} \text { zones to all residential } \\
\text { areas. }\end{array}$ \\
\hline Ecological rent. & Low emissions zone. & $\begin{array}{l}\text { Networks, partnerships, } \\
\text { forum, stimulating sustainable } \\
\text { development ideas. }\end{array}$ \\
\hline $\begin{array}{l}\text { Pedestrian zone, bicycle paths, } \\
\text { low emissions zone. }\end{array}$ & Pedestrian zone, bicycle paths. & $\begin{array}{l}\text { Initiatives promoting energy } \\
\text { saving, sustainable building, } \\
\text { ecological way of live } \\
\text { (f.e. Bristol Green Doors). }\end{array}$ \\
\hline Rentable city bies. & $\begin{array}{l}\text { Green Shipping - reducing } \\
\text { port fees for environmentally } \\
\text { friendly ships; European } \\
\text { alliance for climate-friendly } \\
\text { cruise ships ("cold ironing"). }\end{array}$ & $\begin{array}{l}\text { Network of EV charging } \\
\text { points. }\end{array}$ \\
\hline $\begin{array}{l}\text { Supportnig ecological passive } \\
\text { district - Bahnstadt. }\end{array}$ & Local heating network. & $\begin{array}{l}\text { Promotion the installation of } \\
\text { renewable energy systems in } \\
\text { private homes. }\end{array}$ \\
\hline $\begin{array}{l}\text { Information policy } \\
\text { instruments: } \\
\text { e.g. actions, leaflets. }\end{array}$ & $\begin{array}{l}\text { Information policy } \\
\text { instruments: } \\
\text { e.g. actions, leaflets. }\end{array}$ & $\begin{array}{l}\text { Information policy } \\
\text { instruments: } \\
\text { e.g. actions, leaflets. }\end{array}$ \\
\hline
\end{tabular}

Source: own elaboration.

Earning an award for an environment-friendly city increases the area's popularity, drawing in tourists, building an environmentalist image of the city, increasing its attractiveness relating to a better standard of living, while encouraging migration, settlement and work. Environment-friendly cities are brought together by common goals related to achievements for improving the climate. 
Following the example of environment-friendly cities, other towns in Poland should adopt similar instruments for managing sustainable development. Firstly, it is important to offer numerous climate and resource protection services aimed at motivating businesses and citizens to participate on a voluntary basis. Services could give crucial advice on improving energy efficiency, getting subsidies for investment in resource-saving measures. The exchange of knowledge and experience via these services would be very useful. For instance, the "UmweltPartnerschaft" (Eco-Partnership) network is well developed in Hamburg, where companies are getting free advice on climate protection tools. Secondly, it is necessary to start numerous regional programs, sometimes financed from EU funds, which would limit low emission, support sustainable transport, generate savings in energy use, etc. Thirdly, basic environmental education is an important point and should be provided in schools, but not limited to them. It is necessary to create a network for sharing experiences and information, as was the case, for example, in Hamburg. The city should also, as in Heidelberg, provide opportunities for citizens to take part in making key decisions relating to the directions of development. Social participation strengthens the sense of responsibility for the activities carried out for the region and builds a feeling of the citizens' affiliation with the city.

\section{CONCLUSIONS}

Green cities provide other cities with precious examples of how good quality of life, respect for the environment and economic growth can all be successfully combined to reach sustainable development standards. In 1992 Heidelberg was the first city in Germany to introduce a municipal climate protection concept. The city has established a reputation as a centre of environment and sustainability.

Heidelberg has already received the European Sustainable City Award twice and is one of the model municipalities involved in the German Environment Agency's "Master Plan for 100\% Climate Protection" launched by the Federal Environment Ministry with the aim of achieving carbon-neutrality by 2050. The Aalborg Charter states that municipalities and their citizens have a great responsibility in creating environmental, social and economically sustainable communities.

The future trends of economic development should be built on well-mixed structure of new buildings following ecological criteria (passive standard). Promoting environmentally compatible mobility through electric trams and cars, bicycles by encouraging citizens for using public transport help reducing pollution caused by motorised individual traffic. At the moment the world's largest passive-house project is under development in "Bahnstadt", Heidelberg's new district.

A long-term action plan towards sustainability involves lasting protection of natural resources and saving them for the next generations. The City of Heidel- 
berg intends to reduce the consumption of natural resources using renewables, saving energy, promoting protection of the climate. The establishment of an environmental budgeting scheme plays a vital role for the initiation of sustainable development. The City Council specified the budget so that the natural resources (human health, landscape, air, climate, water, soil, flora, fauna) are treated in the same way, with the same budgetary care as artificial recourse of money. This administration standards follow the sustainable development idea.

The city promotes an urban development with all requirements of social, environmental, spacial and economical compatibility. Drawing conclusions, sustainable development of the city cannot be achieved without direct citizen involvement. The success of the city development relies on creative cooperation between city and its citizens. Therefore a very broad range of information and communication opportunities are offered to promote the environmental awareness. The city of Heidelberg is going to integrate people in decision making process on political and planning matters.

Realization of sustainable development in the city of Heidelberg progresses thanks to the consequent policy of city authorities. The process of integration of political, economic and social activities is visible in the participation of citizens, in their involvement in making decisions about the directions of the city's development. Environmental education of citizens from an early age enables them to shape environmental awareness on a high level, and, most importantly, to understand the idea of sustainable economy. The economic actions taken are consistent with keeping environmental balance and stability of basic natural processes.

\section{REFERENCES}

Bahnstadt, http://heidelberg-bahnstadt.de/en (accessed: 20.10.2014).

Bristol. Smart City (2011), The Covenant of Mayors, http://www.bristolpartnership.org/images/stories/Strategy_Docs/2708_2020_Pla n_AW_3_LORES.pdf (accessed: 20.10.2014).

Bukowski Z. (2005), Pojęcie zrównoważonego rozwoju w prawie polskim, [w:] A. Papuziński (red.), Zrównoważony rozwój od utopii do praw człowieka, Oficyna Wydawnicza Branta, Bydgoszcz.

Core Strategy Policy BCS9 Green Infrastructure (2014), www.bristol.gov.uk/sites/default/files/ documents/planning_and_building_regulations/planning_policy/local_development_framework/Adopted\%20Bristol\%20Core\%20Strategy.pdf (accessed: 12.02.2015).

European Sustainable City Award, Welcome Europe, http://www.welcomeurope.com/eu-fonds/european-sustainable-city-award-408+308.html\#tab=onglet_details (accessed: 20.10.2014).

First European Conference on Sustainable Cities and Towns (1994), http://www.sustainablecities. eu/events/aalborg-1994 (accessed: 20.10.2014).

Heidelberg City Development Plan (1984), Heidelberg City Administration, Heidelberg.

Heidelberg City Development Plan 2015 (2007), Stadt Heidelberg, Amt für Stadtentwicklung und Statistik, March.

Institut für Energie und Umweltforschung, Heidelberg, https://www.ifeu.de (accessed: 20.10.2014). 
Konzept für den Masterplan 100\% Klimaschutz für die Stadt Heidelberg (2014), Institut für Energieund Umweltforschung Heidelberg GmbH, Heidelberg, April.

Lisboa Action Plan: from Charter to Action, http://www.sustainablecities.eu/events/lisbon-1996 (accessed: 20.10.2014).

Maaß Ch. (2014), Hamburg. Application for the Title as European Green Capital. Presentation, http://ec.europa.eu (accessed: 12.02.2015).

Our Common Future (1987), World Commission on Environment and Development (WCED), Oxford University Press, Oxford.

Public Realm and Movement Framework, http://www.bristol.gov.uk/page/planning-and-building-regulations/bristol-centralarea-action-plan (accessed: 12.02.2015).

Stadtentwicklung in Heidelberg aus umweltpolitischer Perspektive (2010), Bund für Umwelt und Naturschutz Deutschland e.V. Kreisgruppe Heidelberg, Heidelberg, December.

The City of Heidelberg, http://www.heidelberg.de/english,Len/Home/Live/Environment +an$\mathrm{d}+$ sustainability.html (accessed: 20.10.2014).

The inteview with dr Raino Winkler (2014), Amt für Umweltschutz, Gewerbeaufsicht und Energie, Prinz-Carl, Kornmarkt 169117 Heidelberg, Heidelberg, July.

UK Department of Energy \& Climate Change (DECC) (2012), http://www.decc.gov.uk/en/content/ cms/statistics/local_auth/co2_las/co2_las.aspx (accessed: 12.02.2015).

\section{Alicja Małgorzata Graczyk}

\section{REALIZACJA ZRÓWNOWAŻONEGO ROZWOJU W HEIDELBERGU}

Streszczenie. Miasto Heidelberg dwukrotnie otrzymało nagrodę Europejskiego Miasta Zrównoważonego. Artykuł przedstawia najnowsze badania autorki (lipiec 2014) dotyczące zrównoważonego rozwoju w Heidelbergu. Celem artykułu jest analiza i ocena działań podjętych w kierunku wdrażania zrównoważonego rozwoju w mieście. W części pierwszej analiza została przeprowadzona pod kątem wdrażania działań prośrodowiskowych. Druga część analizy dotyczy działań ekonomicznych, a trzecia - społecznych. Sposób integracji prowadzonych działań i zastosowanych instrumentów został zaprezentowany w podsumowaniu. We wstępie natomiast zaprezentowana została geneza zrównoważonego rozwoju w Heidelbergu oraz przykłady działań wdrożonych w europejskich „zielonych” miastach. Uzasadnieniem podjętego celu badawczego jest konieczność propagowania pozytywnych wzorców zarządzania miastem zgodnie z ideą zrównoważonego rozwoju. Dlatego też w części finalnej zaprezentowano rekomendacje dla polskich miast.

Słowa kluczowe: zrównoważony rozwój, miasto, wdrażanie, ochrona klimatu. 